\title{
The Changing Spousal Differentials in Socio-demographic Characteristics in Malaysia
}

Nai Peng Tey ${ }^{\mathrm{a}}$

\begin{abstract}
This paper uses matched couple data from the 1991, 2000, and 2010 population censuses to examine the changes in spousal differentials in age, education, and work status, as well as inter-ethnic and international marriages. The general trend is one of decreasing spousal age and educational gaps between 1991 and 2010. Although olderman younger-woman marriages still predominated, the spousal age gap decreased from 4.6 years to 3.9 years, and the proportion of marriages in which the husband was more than 6 years older than the wife declined from 30\% to 24\%. Educational homogamy (couples having the same educational level) rose from $53 \%$ to $64 \%$, while the proportion of women marrying someone of higher education declined from $33 \%$ to $21 \%$. Interethnic marriage hovered around $4.2 \%$ throughout the study period, after rising from less than $1 \%$ in the 1980s. International marriages made up about $1.2 \%$ of all marriages in 2010, up from $0.8 \%$ in 1991. The labour force participation rate of married women had increased significantly, resulting in the rise of dual-income households. The changing spousal differentials in socio-demographic characteristics are bound to alter gender roles and relations that will impact Malaysia's family institution and demographic outcomes.
\end{abstract}

Keywords: Age and educational differentials; Marriage; Spouse; Homogamy; Ethnic groups; Inter-ethnic marriage.

JEL Classification: I210, J120, J100

a Faculty of Business and Economics, Lembah Pantai, University of Malaya, 50603 Kuala Lumpur, Malaysia.Email: teynp@um.edu.my, ORCID: 0000-0003-3707-5033 


\section{Introduction}

The theory of marriage posits that people tend to marry someone similar to themselves (Becker, 1974; Nye and Berardo, 1975). Yet, unions with significant differentials in socio-demographic characteristics are common across the world. Many studies found that women typically marry men who are a few years older than themselves (Casterline et al., 1986; Chen and Chen, 2014; Drefahl, 2010; Qian and Qian, 2014; Utomo, 2014; Yang et al., 2006). Large age differences occur mostly in older male-younger female unions, with the greatest differences occurring in the remarriage of a husband to a first-time bride (Berardo et al., 1993; Hu and Qian, 2019; Shehan et al., 1991; Vera et al., 1985). There is a trend towards a narrower spousal age gap (Chen and Chen, 2014; Mensch, 1986; Utomo, 2014), and an increase in women marrying younger men (Klinger-Vartabedian and Wispe, 1989; Manning et al., 2014; Vera et al., 1985). Carmichael (2011) found that rising education tends to increase the age at first marriage and depress the spousal age gap in less developed countries.

In the past, it was the norm for a man to have more education than his wife. Following the rising education and the accomplishment of gender parity in education, there has been a concurrent increase in educational homogamy (where wife and husband have a similar level of educational attainment) and assortative mating - marriages between highly-educated men and women (Chen and Chen, 2014; Grow et al., 2017; Han, 2010; Heard, 2011; Kalmijn, 1991; Luoh, 2001; Mare, 1991; Piotrowski et al., 2016; Qian, 2017; Qian and Qian, 2017; Schofer and Meyer, 2005; Schwartz and Mare, 2005; Smits et al., 1998; Song, 2009; Utomo, 2014). Women have caught up with men in higher education, and this has resulted in increasing educational homogamy and hypogamy (where the wife is more educated than the husband), with a corresponding decrease in hypergamy (where the wife is less educated than the husband (Esteve et al., 2016). Raymo and Iwasawa (2005) found that change in the availability of potential spouse's accounts for the significant decline in marriage among highly-educated Japanese women, and it also explains substantial changes in educational differences in marriage.

The level of intermarriage is influenced by a multitude of factors such as attitudes, the relative size of ethnic groups, ethnic diversity, sex ratios within each ethnic group, and rising education. Intermarriage rates tend to be higher for the more diverse population, the minority, and the better educated. 
Men and women from minority groups are likely to resolve the shortage of eligible mates by entering inter-ethnic marriages (Giok and Sulaiman, 2013; Nagaraj, 2009). Kalmijn (1998) identified three potential reasons for people not to marry outside their group: the individuals' preference to marry someone with similar characteristics, parental and societal blocks to certain types of marriages, and constraints in exposure to those of a different background.

Increased social interactions brought about by socio-economic development and modernisation have loosened the traditional norms of endogamy (marriage within the same group). In neighbouring Singapore, intermarriage made up about 5\% of all marriages in the 1960s (Hassan and Benjamin, 1973; Kuo and Hassan, 1976), and it was estimated at 11\% in 1997, and 22\% in 2017 (Tan, 2018). In contrast, Malaysia, which had a long history of intermarriage dating back to the pre-colonial time, had a low inter-ethnic marriage rate of just 1\% in the 1980s (Arshat et al., 1988; Giok and Sulaiman, 2013; Tan and Jones, 1990). However, this had increased to about $4.5 \%$ during the period $1991-2000$, and then more rapidly to $11 \%$ in 2019 (DOSM, 2020b; Nagaraj, 2009). A preliminary analysis of the census data indicates that international marriage is also on the rise.

In many societies, women are responsible for a greater portion of the housework (Becker, 1974), but they are also playing an increasingly important role in the economy. The dual-earner situation is the rule rather than the exception in Western families and is also increasingly common among families with young children (Malinen et al., 2010). Concomitant with increasing education and employment opportunities, more married women are entering the workforce, and contribute significantly to family income (Mano and Yamamura, 2013). Young men have become more accepting of wives' contributions to household finances (Barich and Bielby, 1996). An analysis of the Malaysian Labour Force Survey data shows that the proportion of married women engaged in a paid job had increased from $25 \%$ in 1982 to $45.5 \%$ in 2018 , while the proportion working as unpaid family workers declined from $11.9 \%$ to $7.2 \%$ over the same period.

\section{Why do Spousal Gaps in Age and Education Matter?}

The age gap is a very important consideration in mate selection. Owing to normative pressure, the tendency is for women to marry men who are a few years older and are at about the same points in the life course (Shehan et 
al., 1991). Education is often used as a proxy of socio-economic status, and educational sorting is becoming more pervasive and significant (Kalmijn, 1991; Mare, 1991).

Dissimilarities in couples' socio-demographic characteristics are of interest because they have significant effects on the health and wellbeing of each other in a union (Brown et al., 2014; Jaffe et al., 2006; Kravdal, 2008). Heterogamous marriages, especially large age and educational differences between the spouses, are associated with ideational conflict, more patriarchal family systems, less spousal intimacy, domestic violence, poor health, higher mortality, and divorce risks (Blossfeld, 2009; Clarkwest, 2007; Grow et al., 2017; Klinger-Vartabedian and Wispe, 1989; Pearlin, 1975; Rapp et al., 2012; Van de Putte et al., 2009). Studies have found that having a younger spouse is beneficial for men's survival but detrimental for women while having an older spouse is detrimental for both sexes (Drefahl, 2010; Foster et al., 1984). In the United States, women married to younger husbands were found to have lower mortality rates than average, while women married to older husbands are subject to higher mortality rates (Klinger-Vartabedian and Wispe, 1989).

Several studies found that individuals' education and spousal education combine to influence self-rated health within marriage (Brown et al., 2014; Kravdal, 2008; Monden et al., 2003). Moreover, the literature also provides ample evidence of the positive relationship between spousal education and a person's earnings (Amin and Jepsen, 2005; Benham, 1974; Hu and Qian, 2015; Huang et al., 2009; Jolly, 2019; Kenny, 1983; Lefgren and McIntyre, 2006; Mano and Yamamura, 2013; Tiefenthaler, 1997; Yamamura and Mano, 2012). Better-educated women can expect a higher market wage and are more likely to participate in the labour market. According to the theory of cross-productivity, highly-educated women can help improve the human capital of other household members more efficiently than the lowly-educated women through sophisticated conversations or by providing knowledge that improves productivity (Amin and Jepsen, 2005; Benham, 1974; Huang et al., 2009; Mano and Yamamura, 2013).

Past studies on marriage in Malaysia focussed on the increasing age at marriage and non-marriage, and divorce (Arshat et al., 1988; Jones, 1980, 1981; Jones, 2020; Nagaraj, 2009; Tan and Jones, 1990; Tey, 2007, 2011). Less attention has been given to other aspects of marriage such as spousal differentials in socio-demographic characteristics. This paper aims to fill 
the void by analysing the changes in the spousal differentials in age and educational attainment, and inter-ethnic marriage over the period 1991-2010. The census data was also used to shed some light on changes in international marriage, and the roles of women in the household economy.

\section{The Socio-Economic Settings and Changing Marriage Patterns}

Malaysia is a multi-ethnic country, comprising 54.6\% Malays, 12.8\% Other Bumiputera, 24.6\% Chinese, 7.3\% Indians, and 0.7\% Others as of 2010 (DOSM, 2011). Non-citizens made up about 8.4\% of the total population. Malaysia's fertility has fallen to below replacement level, at 1.9 children per woman in 2019, and some segments of the population are having ultra-low fertility. Delayed marriage was found to be the predominant proximate determinant of fertility, and it had a more significant effect on the non-Malays than the Malays (Tey et al., 2012). The rising age at marriage occurred concurrently with the changing family structure. The population censuses show a decline in the proportion of extended family from $26 \%$ in 1991 to $20.5 \%$ in 2010 . The 2014 Malaysian Population and Family Survey shows that parental influence in marriage arrangements is waning, and the lack of childcare support was mentioned as an impediment to family formation (see Abdullah, et al., 2021 in this issue).

The educational level of males and females has risen significantly. Between 1990 and 2018, the tertiary enrolment ratio for males and females had gone up from $7.5 \%$ and $5.6 \%$ to $41 \%$ and $50 \%$ respectively (World Bank, 2021). The Malaysian economy has transformed from an agriculture and commodity-based economy in the post-independence period to a diversified modern economy today. The Labour Force Surveys show that the proportion of workers employed in agriculture declined from $26 \%$ in 1990 to $10.5 \%$ in 2020 , with a corresponding increase in the services sector from $48 \%$ to $64.5 \%$, with those in the manufacturing/construction sector remaining at about $25 \%$.

Migration has contributed significantly to the restructuring of society. Population censuses show that the central region has been the main migration destination, and it is home to $30 \%$ of the national population, up from $20 \%$ in 1970 . The urbanisation level rose from $25 \%$ in 1970 to about $75 \%$ in 2020, and it is the second most urbanised country in Southeast Asia.

All these socio-economic changes have occurred concurrently with 
the demise of universal marriage, and a trend towards age and educational homogamy. Marriage was almost universal until the 1970s. Between 1970 and 2010, the singulate mean age at marriage for women and men rose from 22 years and 25.5 years to 26.7 years and 28 years respectively. Chinese men and women entered marriage two years later than the Malays, with the Indians in between (see Tey, 2007 and Abdullah, et al., 2021 in this issue). Higher education shapes the marriage behaviour of young people. Tertiary education and greater employment opportunities widen the social network of women, providing them with more latitude to choose a life partner from different socio-demographic backgrounds, which might have led to an increase in inter-ethnic and international marriages.

\section{Data and Methods}

This study drew data from the 2\% sample of the 1991, 2000, and 2010 population censuses. In the microdata file, the household members were listed sequentially beginning with the head of household, followed by his or her spouse, and then other family members. A matched couple data set was created for this analysis.

The main dependent variables are spousal gap in age and education, inter-ethnic and international marriages, and per cent of women who were working. The independent variables include gender, ethnicity, region, and education. The ethnic variable comprised five groups, namely Malay, Other Bumiputera, Chinese, Indian, and Others. The six regions used in the analysis are the northern, central, southern, and eastern regions in Peninsular Malaysia, and Sabah/Labuan and Sarawak in East Malaysia. The educational level was categorised as "no education", "primary", "lower secondary", "upper secondary", "pre-University/certificate/diploma", and "degree".

The spousal age gap was obtained by taking the difference between the age of husband and wife, and it was categorised as "woman older than man", "same age", "man older by 1-3 years, 4-6 years, 7-9 years, and 10 years or more". The educational level of the wife was compared to that of the husband, and categorised as "wife better educated than husband", "the same level", and "husband better educated than wife". The inter-ethnic marriage and international marriage each has two categories: 0 if both are from the same ethnic group, 1 otherwise. Likewise, 0 if the spouse is a citizen, and 1 otherwise. 


\section{Results}

\subsection{Spousal age gap}

Between 1991 and 2010, the spousal age gap had declined from 4.6 years to 3.9 years. Except for Other Bumiputera, the spousal age gap had converged at around 3.7-3.9 years for the other three main ethnic groups in 2010. The narrowing of the spousal age gap was most pronounced among the Indians, followed by the Malays and Chinese. In contrast, the marital age gap among the Other Bumiputera remained unchanged at 4.4 years (Figure 1).

Figure 1: Mean Spousal Age Differences by Ethnicity, 1991-2010

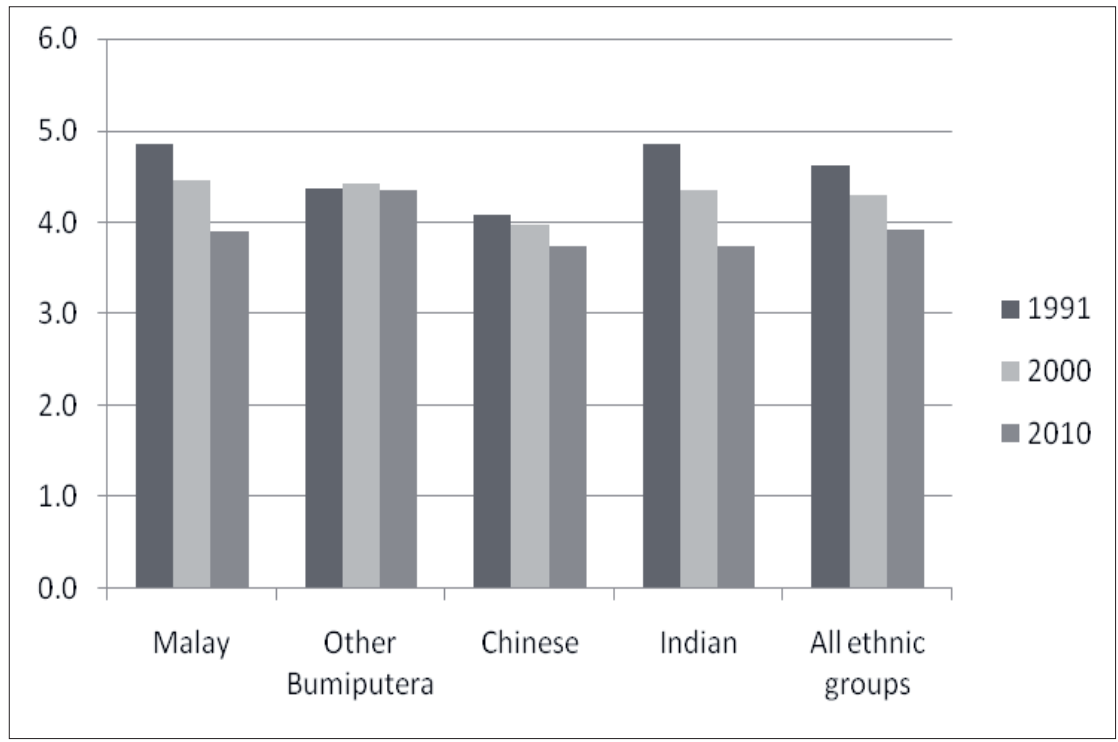

Source: Computed from the $2 \%$ sample of the 1991, 2000, and 2010 population censuses.

The decrease in the spousal age gap was more pronounced in northern and southern regions of Peninsular Malaysia, while it had remained constant in Sarawak, and decreased modestly in Sabah/Labuan. The spousal age gap was smallest in the central region, and largest in Sabah/Labuan (Figure 2). 
Figure 2: Mean Spousal Age Differences by Region, 1991-2010

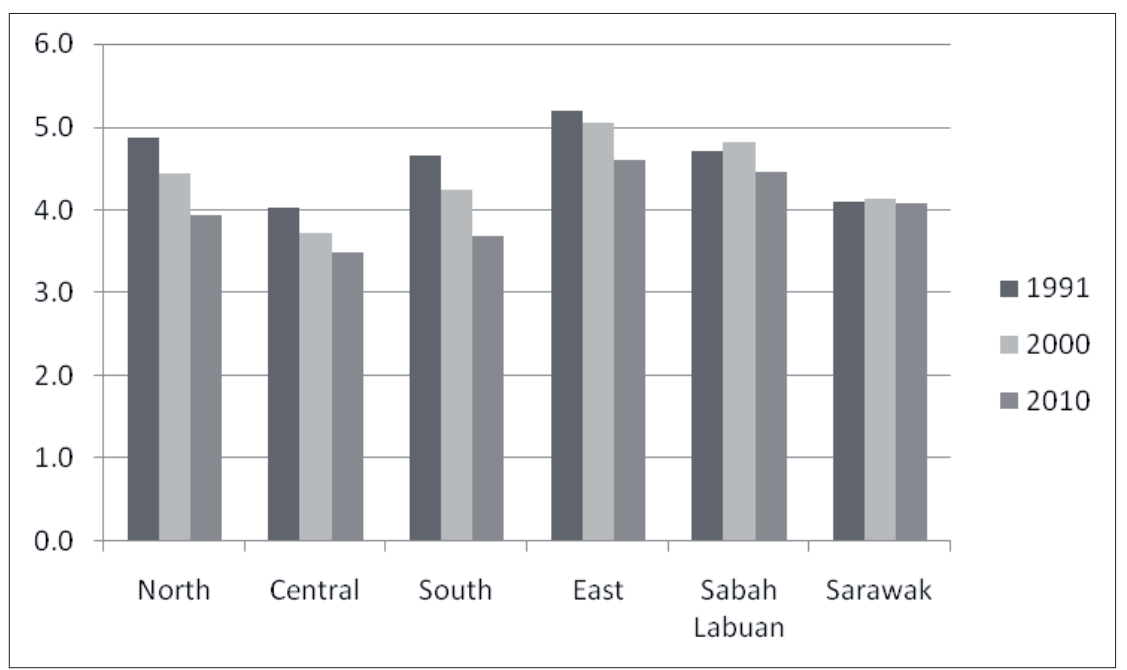

Source: Computed from the 2\% sample of the 1991, 2000, and 2010 population censuses.

The spousal age gap is negatively correlated with women's education, ranging from 2.3 years among the tertiary educated to 5.5 years among those with no schooling in 1991, but there was a narrowing in the spousal age gap across the educational categories. The spousal age gap among those with no schooling decreased from 5.5 years in 1991 to 3.6 years in 2010 but remained unchanged for all the educational categories. In 2010, women with primary or lower secondary education had the largest spousal age gap of close to five years (Figure 3).

The majority of the wives are younger than their husbands. In 2010, one-third of the marriages were between men older than women by 1-3 years, an increase of about 6 percentage points from 1991. In 1991, 30\% of the husbands were 7 or more years older than their wives, but this decreased to $24 \%$ in 2010 . Only $9 \%$ of the marriages were age-homogamous, and $13 \%$ were wife-older in 2010, an increase of 1-2 percentage points since 1991 (Figure 4). 
Figure 3: Mean Spousal Age Differences by Wife's Education, 1991-2010

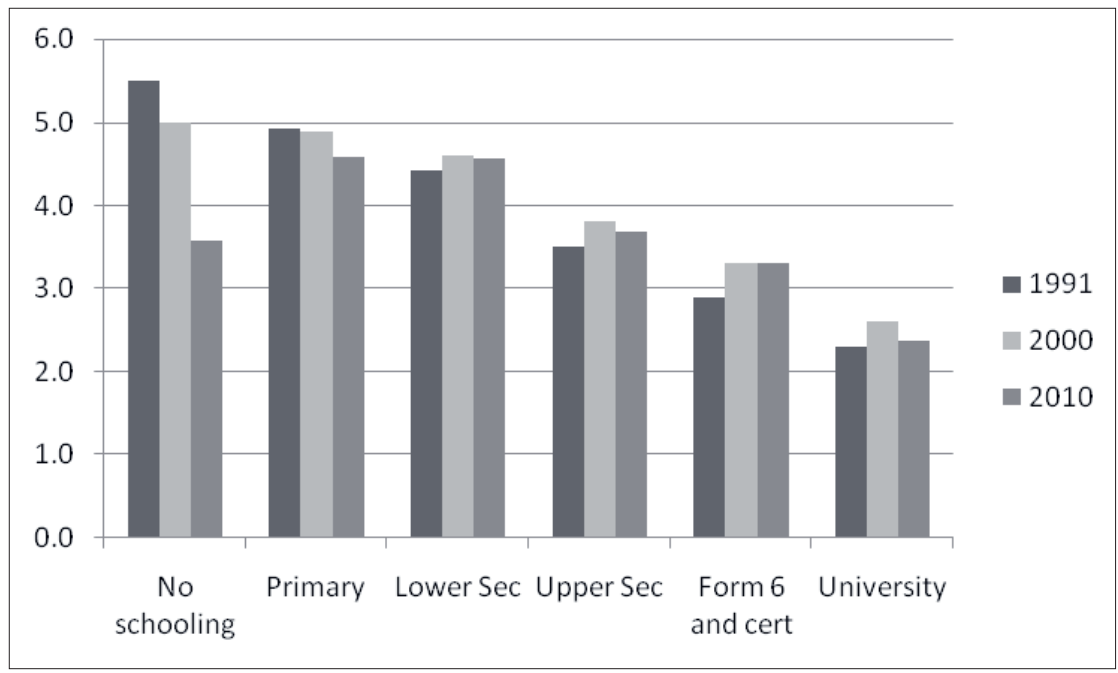

Source: Computed from the $2 \%$ sample of the 1991, 2000, and 2010 population censuses.

Figure 4: Percentage Distribution of Age Gap Between Spouse, 1991-2010

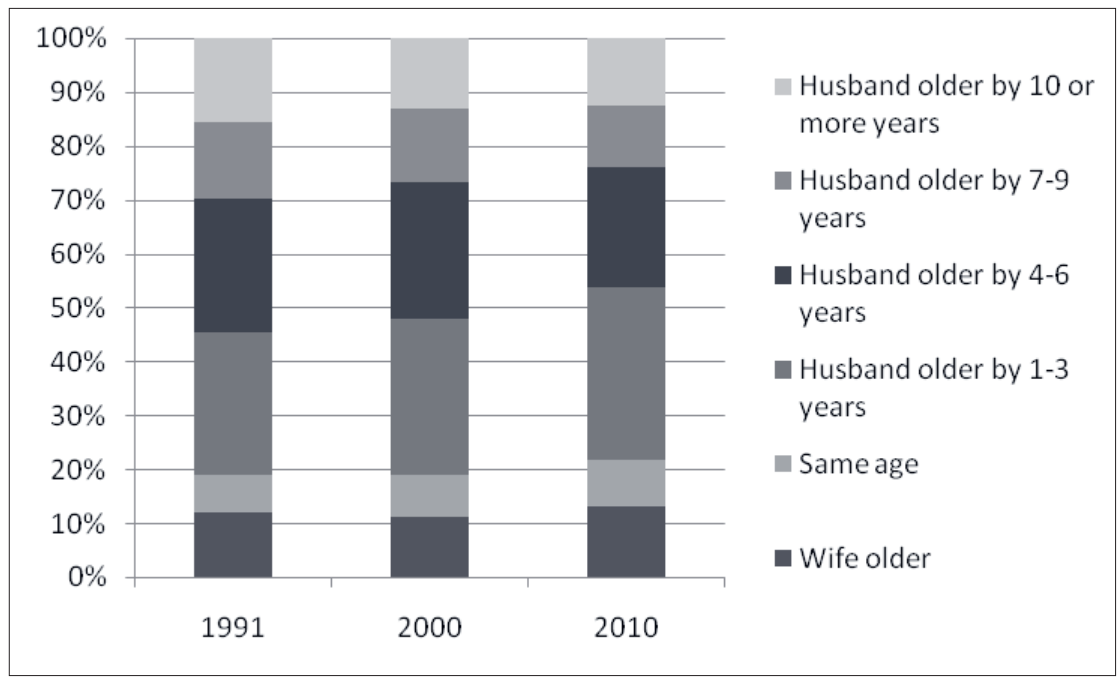

Source: Computed from the 2\% sample of the 1991, 2000, and 2010 population censuses. 
Table 1 shows that the Other Bumiputera women were more likely than women from other ethnic groups to marry men who were at least seven years older, but they were also slightly more likely than others to marry men younger than themselves. Better-educated women were more likely to be age-homogamous than the lesser educated. Women with little or no education were more likely than those with higher education to marry much older men $-29 \%-30 \%$ compared to $11 \%$.

Table 1: Percentage Distribution of Age Gap Between Spouse, by Ethnicity and Education, 2010

\begin{tabular}{|c|c|c|c|c|c|c|c|}
\hline Variables & & $\begin{array}{l}\text { Wife } \\
\text { older }\end{array}$ & $\begin{array}{l}\text { Same } \\
\text { age }\end{array}$ & $\begin{array}{l}\text { Husband } \\
\text { older by } \\
\text { 1-3 years }\end{array}$ & $\begin{array}{l}\text { Husband } \\
\text { older by } \\
\text { 4-6 years }\end{array}$ & $\begin{array}{l}\text { Husband } \\
\text { older by } \\
7+\text { years }\end{array}$ & Total \\
\hline \multirow{4}{*}{$\begin{array}{l}\text { Women's } \\
\text { ethnic } \\
\text { group }\end{array}$} & Malay & 13.4 & 9.0 & 31.7 & 22.2 & 23.7 & 100.0 \\
\hline & $\begin{array}{l}\text { Other } \\
\text { Bumiputera }\end{array}$ & 14.9 & 7.5 & 27.4 & 20.8 & 29.5 & 100.0 \\
\hline & Chinese & 13.4 & 9.6 & 33.8 & 22.3 & 20.9 & 100.0 \\
\hline & Indian & 12.0 & 7.4 & 33.2 & 24.1 & 23.2 & 100.0 \\
\hline \multirow{6}{*}{$\begin{array}{l}\text { Women's } \\
\text { education }\end{array}$} & $\begin{array}{l}\text { No } \\
\text { schooling }\end{array}$ & 17.0 & 6.8 & 25.6 & 21.9 & 28.6 & 100.0 \\
\hline & Primary & 11.6 & 6.4 & 27.3 & 24.5 & 30.1 & 100.0 \\
\hline & $\begin{array}{l}\text { Lower } \\
\text { secondary }\end{array}$ & 11.2 & 6.5 & 29.4 & 24.8 & 28.0 & 100.0 \\
\hline & $\begin{array}{l}\text { Upper } \\
\text { secondary }\end{array}$ & 12.2 & 9.2 & 34.8 & 22.9 & 20.8 & 100.0 \\
\hline & $\begin{array}{l}\text { Pre- } \\
\text { University/ } \\
\text { certificate/ } \\
\text { diploma }\end{array}$ & 14.4 & 12.5 & 36.1 & 20.5 & 16.5 & 100.0 \\
\hline & Degree & 16.0 & 16.5 & 40.1 & 16.5 & 10.9 & 100.0 \\
\hline
\end{tabular}

Source: Computed from the $2 \%$ sample of the 2010 population census.

The spousal age gap was smaller if both men and women had at least lower secondary education compared to those who had primary education. On the other hand, those with no schooling had the widest gap. Those in educational heterogamous unions had a wider spousal age gap than those in homogamous unions. The age gap decreases with the educational level of both husband and wife (Figure 5). 
Figure 5: Mean Spousal Age Differences by Husband's and Wife's Educational Levels, 2010

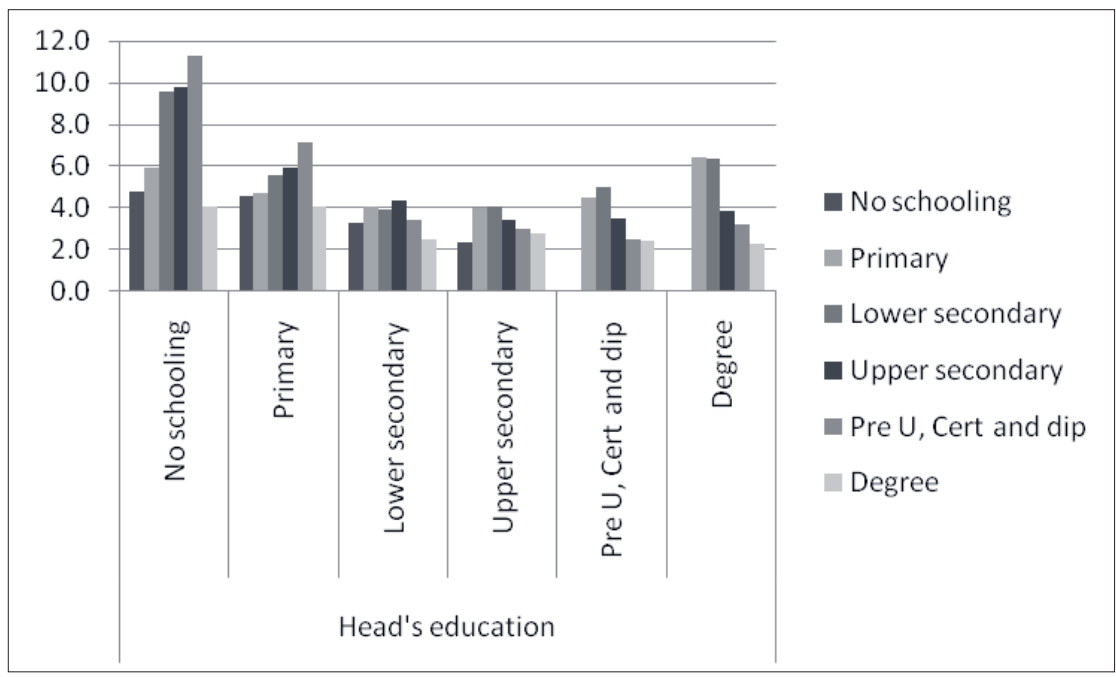

Note: Husband's education is shown on the x-axis and wife's education on the y-axis. Source: Computed from the $2 \%$ sample of the 2010 population census.

\subsection{Spousal gap in education}

Women have surpassed men in education since the 1990s, with a corresponding rise in educational homogamy. Between 1991 and 2010, the proportion of couples with the same educational level rose from $53 \%$ to $64 \%$, while the proportion of women marrying someone of higher education than themselves declined from $33 \%$ to $21 \%$. About $16 \%$ of the married women in 2000 and 2010 had more education than their husbands, compared to $14 \%$ in 1991 (Table 2).

Couples from the central and southern regions and Sabah/Labuan were more likely to have the same educational level compared to those from the other regions. In 2010, about $28 \%$ of Sarawak's women married better-educated husbands, compared to close to $20 \%$ for the other five regions. Spousal differentials in educational level can be observed across ethnic groups. Malays and Chinese were more likely to be homogamous in education compared to the Other Bumiputera and the Indians. Malay women were the most likely to be better educated than husbands (17.6\%), while the 
Chinese were least likely (12.9\%). However, Chinese couples were more likely than Malays to have the same education level. Married women aged below 30 were almost twice as likely as those in their 50 s to marry lessereducated men (18.5\% compared to 9.7\%) (table not shown).

Table 2: Comparison of Husband's and Wife's Educational Level, by Ethnicity and Region, 1991-2010

\begin{tabular}{|c|c|c|c|c|}
\hline Variables & Comparing spousal educational level & 1991 & 2000 & 2010 \\
\hline Total & & 100.0 & 100.0 & 100.0 \\
\hline \multirow[t]{3}{*}{ Malaysia } & Wife more educated than husband & 14.1 & 15.8 & 15.7 \\
\hline & Husband and wife same education & 52.8 & 54.6 & 63.7 \\
\hline & Husband more educated than wife & 33.1 & 29.6 & 20.6 \\
\hline \multicolumn{5}{|c|}{ Ethnic group } \\
\hline \multirow[t]{3}{*}{ Malay } & Wife more educated than husband & 15.7 & 17.1 & 17.6 \\
\hline & Husband and wife same education & 53.0 & 55.2 & 62.9 \\
\hline & Husband more educated than wife & 31.3 & 27.7 & 19.5 \\
\hline \multirow{3}{*}{$\begin{array}{l}\text { Other } \\
\text { Bumiputera }\end{array}$} & Wife more educated than husband & 9.7 & 12.7 & 13.5 \\
\hline & Husband and wife same education & 57.0 & 53.5 & 59.5 \\
\hline & Husband more educated than wife & 33.3 & 33.8 & 26.9 \\
\hline \multirow[t]{3}{*}{ Chinese } & Wife more educated than husband & 12.6 & 14.6 & 12.9 \\
\hline & Husband and wife same education & 51.8 & 55.2 & 67.4 \\
\hline & Husband more educated than wife & 35.7 & 30.2 & 19.6 \\
\hline \multirow[t]{3}{*}{ Indian } & Wife more educated than husband & 14.1 & 15.8 & 16.9 \\
\hline & Husband and wife same education & 49.5 & 51.0 & 59.9 \\
\hline & Husband more educated than wife & 36.5 & 33.2 & 23.3 \\
\hline \multicolumn{5}{|l|}{ Region } \\
\hline \multirow[t]{3}{*}{ North } & Wife more educated than husband & 13.6 & 16.6 & 17.0 \\
\hline & Husband and wife same education & 52.1 & 54.5 & 62.6 \\
\hline & Husband more educated than wife & 34.3 & 28.8 & 20.4 \\
\hline \multirow[t]{3}{*}{ Central } & Wife more educated than husband & 15.3 & 14.6 & 14.8 \\
\hline & Husband and wife same education & 50.6 & 56.0 & 65.4 \\
\hline & Husband more educated than wife & 34.2 & 29.4 & 19.9 \\
\hline \multirow[t]{3}{*}{ South } & Wife more educated than husband & 13.6 & 15.9 & 14.8 \\
\hline & Husband and wife same education & 53.1 & 55.1 & 65.4 \\
\hline & Husband more educated than wife & 33.3 & 29.0 & 19.9 \\
\hline
\end{tabular}




\begin{tabular}{llccc}
\hline Variables & Comparing spousal educational level & $\mathbf{1 9 9 1}$ & $\mathbf{2 0 0 0}$ & $\mathbf{2 0 1 0}$ \\
\hline East & Wife more educated than husband & 16.4 & 18.7 & 19.0 \\
& Husband and wife same education & 55.0 & 53.4 & 61.6 \\
& Husband more educated than wife & 28.6 & 27.9 & 19.4 \\
\hline Sabah/ & Wife more educated than husband & 12.5 & 14.3 & 12.4 \\
Labuan & & & & \\
& Husband and wife same education & 54.5 & 51.2 & 65.7 \\
& Husband more educated than wife & 33.0 & 34.5 & 21.9 \\
\hline Sarawak & Wife more educated than husband & 11.1 & 13.3 & 14.5 \\
& Husband and wife same education & 53.8 & 54.4 & 57.4 \\
& Husband more educated than wife & 35.0 & 32.3 & 28.1 \\
\hline
\end{tabular}

Source: Computed from the 2\% sample of the 1991, 2000, and 2010 population censuses.

Tables 3 shows that the proportion of men who had the same or lower education ranged from $43.1 \%$ for those with a degree to $81.7 \%$ for those with no schooling. The corresponding figures for the women were $32.5 \%$ and $59.8 \%$ respectively (Table 4). Women were more likely than men to "marry up" educationally - with the proportion marrying men with more

Table 3: Wife's Educational Level by Husband's Education, 2010

\begin{tabular}{|c|c|c|c|c|c|c|c|}
\hline \multirow[b]{2}{*}{$\begin{array}{l}\text { Women's } \\
\text { education }\end{array}$} & \multicolumn{7}{|c|}{ Men's education } \\
\hline & $\begin{array}{c}\text { No } \\
\text { schooling }\end{array}$ & Primary & $\begin{array}{l}\text { Lower } \\
\text { secondary }\end{array}$ & $\begin{array}{c}\text { Upper } \\
\text { secondary }\end{array}$ & $\begin{array}{c}\text { Pre- } \\
\text { University/ } \\
\text { certificate/ } \\
\text { diploma }\end{array}$ & Degree & Total \\
\hline $\begin{array}{l}\text { No } \\
\text { schooling }\end{array}$ & 81.7 & 13.9 & 4.8 & 1.6 & 1.2 & 0.7 & 10.7 \\
\hline Primary & 11.1 & 63.1 & 17.0 & 5.2 & 1.8 & 0.7 & 18.4 \\
\hline $\begin{array}{l}\text { Lower } \\
\text { secondary }\end{array}$ & 3.7 & 12.8 & 48.1 & 10.6 & 4.7 & 1.6 & 15.1 \\
\hline $\begin{array}{l}\text { Upper } \\
\text { secondary }\end{array}$ & 3.0 & 8.9 & 26.5 & 72.5 & 33.4 & 20.4 & 38.6 \\
\hline $\begin{array}{l}\text { Pre- } \\
\text { University/ } \\
\text { certificate/ } \\
\text { diploma }\end{array}$ & 0.5 & 0.9 & 2.9 & 7.6 & 48.6 & 19.6 & 10.3 \\
\hline Degree & 0.1 & 0.3 & 0.7 & 2.6 & 10.3 & 56.9 & 6.9 \\
\hline Total & 100.0 & 100.0 & 100.0 & 100.0 & 100.0 & 100.0 & 100.0 \\
\hline
\end{tabular}

Source: Computed from the $2 \%$ sample of the 2010 population census. 
Table 4: Husband's Educational Level by Wife's Education, 2010

\begin{tabular}{|c|c|c|c|c|c|c|c|}
\hline \multirow[b]{2}{*}{$\begin{array}{l}\text { Men's } \\
\text { education }\end{array}$} & \multicolumn{7}{|c|}{ Women's education } \\
\hline & $\begin{array}{c}\text { No } \\
\text { schooling }\end{array}$ & Primary & $\begin{array}{l}\text { Lower } \\
\text { secondary }\end{array}$ & $\begin{array}{c}\text { Upper } \\
\text { secondary }\end{array}$ & $\begin{array}{c}\text { Pre- } \\
\text { University/ } \\
\text { certificate/ } \\
\text { diploma }\end{array}$ & Degree & Total \\
\hline $\begin{array}{l}\text { No } \\
\text { schooling }\end{array}$ & 59.8 & 4.7 & 1.9 & 0.6 & 0.4 & 0.1 & 7.8 \\
\hline Primary & 25.9 & 68.5 & 16.8 & 4.6 & 1.8 & 0.8 & 19.9 \\
\hline $\begin{array}{l}\text { Lower } \\
\text { secondary }\end{array}$ & 7.1 & 14.8 & 51.0 & 11.0 & 4.5 & 1.6 & 16.0 \\
\hline $\begin{array}{l}\text { Upper } \\
\text { secondary }\end{array}$ & 5.4 & 10.5 & 26.1 & 70.2 & 27.5 & 14.1 & 37.4 \\
\hline $\begin{array}{l}\text { Pre- } \\
\text { University/ } \\
\text { certificate/ } \\
\text { diploma }\end{array}$ & 1.1 & 1.0 & 3.4 & 9.3 & 50.3 & 16.0 & 10.7 \\
\hline Degree & 0.6 & 0.3 & 0.8 & 4.3 & 15.5 & 67.5 & 8.1 \\
\hline Total & 100.0 & 100.0 & 100.0 & 100.0 & 100.0 & 100.0 & 100.0 \\
\hline
\end{tabular}

Source: Computed from the $2 \%$ sample of the 2010 population census.

education ranging from $13.6 \%$ among those with pre-university, certificate, and diploma level to almost $40 \%$ among those with no schooling. For those who had a degree, only $0.9 \%$ of the women and $1.4 \%$ of the men had a spouse with primary or no schooling.

\subsection{Inter-ethnic marriage}

Inter-ethnic marriage in Peninsular Malaysia had increased from less than $1 \%$ in the 1980s (Arshat et al., 1988) to about 3\% in 2000 (Tey, 2007). For the country as a whole, data from the population census showed a slight dip in inter-ethnic marriage from $4.6 \%$ in 1991 and 2000 to $4.2 \%$ in 2010 . The highest proportion of inter-ethnic marriages was in Sabah/Labuan, at about $15.5 \%$ in 1991 and 2000 , but had declined rather sharply to $10.9 \%$ in 2010. Sarawak had the second-highest inter-ethnic marriage rate, rising from $6.6 \%$ in 1991 to $7.9 \%$ in 2010 . The high prevalence of intermarriage in these two regions can be attributed to the diverse ethnic population. In contrast, the low level of inter-ethnic marriage in the eastern and northern regions in Peninsular Malaysia is due to the demographic predominance of ethnic Malays. Among the main ethnic groups, the Other Bumiputera had the 
highest rate of marrying out, and the Malays were least likely to do so. Being the minority, a very high proportion of Others had married out. Except for the Other Bumiputera, the males from each of the main ethnic groups were more likely than their female counterparts to marry out, especially among the Chinese (Table 5).

Table 5: Share of Inter-ethnic Marriages of Total Marriages, by Region, Ethnicity, and Gender, 1991-2010 (\%)

\begin{tabular}{|c|c|c|c|c|}
\hline Variables & & 1991 & 2000 & 2010 \\
\hline \multirow{7}{*}{ Region } & Malaysia & 4.6 & 4.6 & 4.2 \\
\hline & North & 2.1 & 2.2 & 2.3 \\
\hline & Central & 4.0 & 3.7 & 3.6 \\
\hline & South & 4.5 & 3.6 & 4.0 \\
\hline & East & 2.0 & 2.3 & 2.0 \\
\hline & Sabah/Labuan & 15.5 & 15.4 & 10.9 \\
\hline & Sarawak & 6.6 & 7.1 & 7.9 \\
\hline \multicolumn{5}{|l|}{ Male } \\
\hline \multirow[t]{5}{*}{ Ethnicity } & Malay & 2.5 & 2.5 & 2.1 \\
\hline & $\begin{array}{l}\text { Other } \\
\text { Bumiputera }\end{array}$ & 7.8 & 7.9 & 7.6 \\
\hline & Chinese & 2.4 & 3.5 & 4.2 \\
\hline & Indian & 5.3 & 4.3 & 4.7 \\
\hline & Others & 31.2 & 38.6 & 42.1 \\
\hline \multicolumn{5}{|l|}{ Female } \\
\hline \multirow[t]{5}{*}{ Ethnicity } & Malay & 2.4 & 2.0 & 1.5 \\
\hline & $\begin{array}{l}\text { Other } \\
\text { Bumiputera }\end{array}$ & 10.4 & 10.4 & 9.4 \\
\hline & Chinese & 1.9 & 2.1 & 2.3 \\
\hline & Indian & 3.1 & 2.4 & 3.3 \\
\hline & Others & 25.0 & 42.8 & 48.5 \\
\hline
\end{tabular}

Source: Computed from the 2\% sample of the 1991, 2000, and 2010 population censuses.

Among the Malay males and females who had a spouse from another ethnic group, the majority had married a non-citizen or Other Bumiputera. Among the Other Bumiputera, the males were more likely to marry a Malay or a non-citizen, but the females were more likely to marry a Chinese or a Malay than an Indian or Others. The Chinese were more likely to marry 
Other Bumiputera or non-citizen rather than a Malay or an Indian. Indian males and females were more likely to marry a Chinese or a non-citizen rather than a Malay or Other Bumiputera (Tables 6 and 7). An inspection of the 2010 population census data shows that there were no consistent patterns in inter-ethnic marriage across women's educational levels, ranging from $3.5 \%$ among those with upper secondary education to about $4.4 \%-4.5 \%$ among those with primary and tertiary education.

Table 6: Percentage Distribution of Wife's Ethnicity by Husband's Ethnicity, 2010

\begin{tabular}{lccccccc}
\hline \multicolumn{7}{c}{ Men's ethnic group } \\
$\begin{array}{l}\text { Women's } \\
\text { ethnic group }\end{array}$ & Malay & $\begin{array}{c}\text { Other } \\
\text { Bumiputera }\end{array}$ & Chinese & Indian & Others & $\begin{array}{c}\text { Non- } \\
\text { citizen }\end{array}$ & Total \\
\hline Malay & 97.9 & 2.8 & 0.2 & 0.6 & 7.4 & 6.9 & 52.4 \\
$\begin{array}{l}\text { Other } \\
\text { Bumiputera }\end{array}$ & 0.7 & 92.4 & 1.5 & 0.7 & 12.5 & 2.9 & 10.3 \\
Chinese & 0.1 & 1.7 & 95.8 & 1.5 & 15.1 & 2.8 & 24.2 \\
Indian & 0.0 & 0.2 & 0.5 & 95.3 & 3.1 & 1.0 & 7.0 \\
Others & 0.1 & 0.4 & 0.5 & 0.4 & 57.9 & 0.7 & 0.5 \\
Non-citizen & 1.2 & 2.3 & 1.6 & 1.4 & 4.9 & 85.7 & 5.7 \\
Total & 100.0 & 100.0 & 100.0 & 100.0 & 100.0 & 100.0 & 100.0 \\
Intermarriage & 2.1 & 7.6 & 4.2 & 4.7 & 42.1 & 14.3 & \\
\hline
\end{tabular}

Source: Computed from the $2 \%$ sample of the 2010 population census.

Table 7: Percentage Distribution of Husband's Ethnicity by Wife's Ethnicity, 2010

\begin{tabular}{lccccccc}
\hline \multicolumn{7}{c}{ Women's ethnic group } \\
\hline $\begin{array}{l}\text { Men's ethnic } \\
\text { group }\end{array}$ & Malay & $\begin{array}{c}\text { Other } \\
\text { Bumiputera }\end{array}$ & Chinese & Indian & Others & $\begin{array}{c}\text { Non- } \\
\text { citizen }\end{array}$ & Total \\
\hline Malay & 98.5 & 3.4 & 0.2 & 0.3 & 8.6 & 11.0 & 52.7 \\
$\begin{array}{l}\text { Other } \\
\text { Bumiputera }\end{array}$ & 0.5 & 90.6 & 0.7 & 0.3 & 8.4 & 4.0 & 10.0 \\
Chinese & 0.1 & 3.5 & 97.7 & 1.7 & 20.9 & 6.8 & 24.7 \\
Indian & 0.1 & 0.4 & 0.5 & 96.7 & 4.8 & 1.8 & 7.1 \\
Others & 0.1 & 0.6 & 0.3 & 0.2 & 51.5 & 0.4 & 0.5 \\
Non-citizen & 0.7 & 1.4 & 0.6 & 0.7 & 6.6 & 76.0 & 5.0 \\
Total & 100.0 & 100.0 & 100.0 & 100.0 & 100.0 & 100.0 & 100.0 \\
Intermarriage & 1.5 & 9.4 & 2.3 & 3.3 & 48.5 & 24.0 & \\
\hline
\end{tabular}

Source: Computed from the $2 \%$ sample of the 2010 population census. 


\subsection{International marriage}

Information on the citizenship status of the spouse at the time of the census was used to estimate the proportion of marriages with a non-citizen. This is a crude estimate as it does not take into account marital dissolution. Any change in citizenship after marriage is unlikely to affect the accuracy of the estimate of international marriage, because of the long and arduous process for a non-citizen spouse to obtain permanent residency status, not to mention citizenship. Under the immigration law, a foreign spouse must be married to a Malaysian for a minimum period of five years and must have stayed continuously in Malaysia for a period of five years on a Long-Term Social Visit Pass, before a permanent residency application can be made.

Data from population censuses show that marriages with a non-citizen made up about $1.2 \%$ of all marriages in 2010, up from about $0.8 \%$ in 1991 . Males were much more likely than females to marry non-citizens, especially among the Chinese and Indians. The Others, comprising many minority groups, were the most likely to marry a non-citizen.

Except for the Indians and Chinese women, the highest proportion of non-citizen spouses were from Indonesia, making up $60 \%$ for the Malays. Many Other Bumiputera were married to Filipinos. About two-thirds of the foreign spouses of the Indians came from India, and almost half of the Chinese women's foreign spouses were from China. The source country of non-citizen spouses varied significantly between the males and females (Table 8).

\subsection{Spousal work status - single-earner and dual-earner households}

This sub-section discusses the couples' work status among families whose household heads were below 60 years old, the mandatory retirement age. As more women entered the labour market, the proportion of dual-earner households had increased from $30.9 \%$ in 1991 to $40.2 \%$ in 2010 , with a corresponding decline in the proportion of families with husband as the sole breadwinner from about $61 \%$ to $49 \%$. The wife was the sole breadwinner in about $2 \%$ to $3.5 \%$ of the households. As the terms "sole breadwinner" and "single-earner family" imply that there were no other working members in the family, these figures may be slightly over-estimated for the older couples, if they had working children staying with them. The proportion of families 
Table 8: Share of Malaysian Men and Women Aged below 50 Who were Married to a Non-Citizen, 1991-2010 (\%), and Country of Citizenship of Spouse, 2010

\begin{tabular}{|c|c|c|c|c|c|c|c|}
\hline Year & & Malay & $\begin{array}{c}\text { Other } \\
\text { Bumiputera }\end{array}$ & Chinese & Indian & Others & Malaysia \\
\hline \multirow[t]{2}{*}{1991} & Male & 0.7 & 2.0 & 0.6 & 0.3 & 8.9 & 1.0 \\
\hline & Female & 0.4 & 1.9 & 0.1 & 0.1 & 5.4 & 0.6 \\
\hline \multirow[t]{2}{*}{2000} & Male & 1.2 & 2.0 & 1.2 & 1.9 & 14.5 & 1.5 \\
\hline & Female & 1.0 & 1.4 & 0.4 & 0.5 & 6.7 & 0.9 \\
\hline \multirow[t]{2}{*}{2010} & Male & 1.3 & 2.5 & 2.0 & 1.4 & 5.6 & 1.6 \\
\hline & Female & 0.7 & 1.6 & 0.5 & 0.7 & 8.3 & 0.8 \\
\hline \multicolumn{8}{|c|}{ Spouse's country of citizenship } \\
\hline \multirow[t]{10}{*}{2010} & Male & & & & & & \\
\hline & Indonesia & 58.7 & 50.4 & 32.1 & 16.0 & 38.5 & 46.7 \\
\hline & Thailand & 22.4 & & 12.8 & 2.0 & 7.7 & 14.2 \\
\hline & Singapore & 4.7 & 1.5 & 0.9 & 4.0 & & 3.0 \\
\hline & Philippines & 1.4 & 30.7 & 9.2 & 6.0 & 30.8 & 9.5 \\
\hline & China & & & 16.1 & & & 4.5 \\
\hline & Vietnam & & & 12.8 & 2.0 & & 3.7 \\
\hline & India & 2.5 & & & 64.0 & & 5.3 \\
\hline & Pakistan & & & & 2.0 & & 0.1 \\
\hline & $\begin{array}{l}\text { All other } \\
\text { countries }\end{array}$ & 10.3 & 17.4 & 25.3 & 4.0 & 23.0 & 13.1 \\
\hline \multirow[t]{10}{*}{2010} & Female & & & & & & \\
\hline & Indonesia & 61.7 & 46.2 & 5.9 & 3.3 & 48.1 & 45.3 \\
\hline & Thailand & 3.9 & 1.0 & 2.9 & & 3.7 & 2.8 \\
\hline & Singapore & 7.0 & 1.0 & 13.2 & 3.3 & & 5.9 \\
\hline & Philippines & & 22.1 & & & 11.1 & 5.9 \\
\hline & China & & 1.9 & 47.1 & & & 7.6 \\
\hline & India & 3.5 & 1.0 & & 66.7 & & 6.3 \\
\hline & Bangladesh & 1.3 & 1.0 & & 10.0 & 3.7 & 1.7 \\
\hline & Pakistan & 7.4 & 1.9 & 1.5 & 3.3 & 3.7 & 4.8 \\
\hline & $\begin{array}{l}\text { All other } \\
\text { countries }\end{array}$ & 15.2 & 23.9 & 29.4 & 13.4 & 29.7 & 19.7 \\
\hline
\end{tabular}

Source: Computed from the $2 \%$ sample of the 2010 population census. 
with both husband and wife not working had increased from about $5 \%$ in $1991 / 2000$ to $7.8 \%$ in 2010 ; however, confining the analysis to household heads below 40 years, this proportion was $1.8 \%$ in 1991 and $4.1 \%$ in 2010 (Table 9).

Table 9: Spouse Joint Work Status by Women's Ethnicity and Educational level, 19912010

\begin{tabular}{|c|c|c|c|c|}
\hline Variables & Couples' work status & 1991 & 2000 & 2010 \\
\hline Total & & 100.0 & 100.0 & 100.0 \\
\hline \multirow[t]{4}{*}{ Malaysia } & Both not working & 5.0 & 4.9 & 7.8 \\
\hline & Wife working husband not working & 3.5 & 2.0 & 3.1 \\
\hline & Husband working wife not working & 60.6 & 58.1 & 48.8 \\
\hline & Both working & 30.9 & 35.1 & 40.2 \\
\hline \multirow[t]{4}{*}{ Malay } & Both not working & 4.8 & 4.4 & 7.4 \\
\hline & Wife working husband not working & 3.2 & 1.8 & 3.0 \\
\hline & Husband working wife not working & 63.0 & 59.1 & 47.9 \\
\hline & Both working & 29.1 & 34.7 & 41.8 \\
\hline \multirow[t]{4}{*}{ Other Bumiputera } & Both not working & 3.3 & 6.8 & 7.1 \\
\hline & Wife working husband not working & 4.0 & 2.4 & 3.5 \\
\hline & Husband working wife not working & 56.5 & 60.2 & 59.2 \\
\hline & Both working & 36.2 & 30.6 & 30.2 \\
\hline \multirow[t]{4}{*}{ Chinese } & Both not working & 6.1 & 5.2 & 8.8 \\
\hline & Wife working husband not working & 3.6 & 2.1 & 3.2 \\
\hline & Husband working wife not working & 60.0 & 57.1 & 45.6 \\
\hline & Both working & 30.2 & 35.6 & 42.4 \\
\hline \multirow[t]{4}{*}{ Indian } & Both not working & 5.2 & 4.4 & 9.3 \\
\hline & Wife working husband not working & 4.7 & 2.5 & 3.7 \\
\hline & Husband working wife not working & 50.5 & 51.6 & 50.0 \\
\hline & Both working & 39.6 & 41.6 & 37.1 \\
\hline \multirow[t]{4}{*}{ No schooling } & Both not working & 13.9 & 10.9 & 14.1 \\
\hline & Wife working husband not working & 2.5 & 1.6 & 3.2 \\
\hline & Husband working wife not working & 62.8 & 62.6 & 62.1 \\
\hline & Both working & 20.8 & 25.0 & 20.6 \\
\hline \multirow[t]{4}{*}{ Primary } & Both not working & 13.0 & 7.6 & 13.1 \\
\hline & Wife working husband not working & 2.4 & 1.7 & 2.8 \\
\hline & Husband working wife not working & 66.5 & 70.2 & 65.9 \\
\hline & Both working & 18.1 & 20.5 & 18.2 \\
\hline
\end{tabular}




\begin{tabular}{llccc}
\hline Variables & Couples' work status & $\mathbf{1 9 9 1}$ & $\mathbf{2 0 0 0}$ & $\mathbf{2 0 1 0}$ \\
\hline Lower secondary & Both not working & 9.0 & 4.0 & 9.1 \\
& Wife working husband not working & 2.2 & 1.1 & 2.5 \\
& Husband working wife not working & 68.6 & 71.0 & 68.0 \\
& Both working & 20.2 & 23.9 & 20.4 \\
Upper secondary & Both not working & 5.9 & 2.5 & 5.9 \\
& Wife working husband not working & 2.1 & 1.4 & 2.3 \\
& Husband working wife not working & 57.5 & 54.7 & 57.0 \\
& Both working & 34.5 & 41.4 & 34.7 \\
Pre-University & Both not working & 4.0 & 1.7 & 4.1 \\
& Wife working husband not working & 3.1 & 1.8 & 3.3 \\
& Husband working wife not working & 26.4 & 37.3 & 26.3 \\
& Both working & 66.5 & 59.1 & 66.4 \\
& Both not working & 3.3 & .9 & 2.1 \\
& Wife working husband not working & 3.7 & 1.8 & 3.1 \\
& Husband working wife not working & 13.7 & 17.2 & 13.7 \\
& Both working & 79.2 & 80.0 & 81.1 \\
\hline
\end{tabular}

Source: Computed from the $2 \%$ sample of the 1991, 2000, and 2010 population censuses.

Pronounced ethnic variations in couples' work status can be observed. Among Malay and Chinese couples, the proportion of families with both husband and wife working increased from about $30 \%$ in 1991 to $42 \%$ in 2010, consistent with that of the national figures. Among Other Bumiputera, the proportion of husbands as the sole breadwinner had increased slightly from $56.5 \%$ in 1991 to $59.2 \%$ in 2010 , as households with both husband and wife working declined from $36 \%$ to $30 \%$. The Indians had the highest proportion of both husband and wife not working, at 9.3\% in 2010, up from $4.4 \%$ in 2000 . The Indian men were the sole breadwinner in about half of the households, and the proportion of dual-income households had decreased from about $42 \%$ in 2000 to $37 \%$ in 2010 .

Female labour force participation rate is strongly correlated with educational level. Among women with a degree, $84 \%$ were working, with $3.1 \%$ as the sole breadwinner, and this remained about the same over the $1991-2010$ period. In contrast, only about $22 \%-25 \%$ of the women with lower secondary, primary, or no schooling participated in the labour market. A much higher proportion of the better-educated women were engaged in paid jobs compared to the less-educated. 


\section{Discussion}

Concomitant with development, social changes, and rising education, the spousal differentials in age and education had narrowed considerably between 1991 and 2010. Over this period, the spousal age gap had declined from 4.6 years to 3.9 years. This gap is lower than 4.7 years reported for Indonesia (Utomo, 2014), but higher than the average of about 3 years for most Western countries (Drefahl, 2010). The narrowing of the spousal age gap may result in a reduction in the gender gap in widowhood. Men are not only older than their wives but also have a shorter life expectancy about $40 \%$ of the women aged 60 and over were widowed compared to $11 \%$ among the males, as of 2010 . Older women, especially those who are widowed, are generally more vulnerable than the rest and require assistance.

The spousal age gap is inversely related to development, being smallest in the more developed central region and largest in the eastern region and Sabah/Labuan, the two least developed regions. Consistent with findings from past studies in Asian countries (Chen and Chen, 2014; Utomo, 2014), the spousal age gap is inversely associated with education. Degree-holder women on average married men 2.4 years older, compared to 4.6 years among women with primary or lower secondary education. With rising education, the spousal age gap can be expected to decrease further. However, as pointed out by Chen and Chen (2014) and Raymo and Iwasawa (2005), if women postpone marriage to older ages, their chances of marrying men with equivalent education decrease significantly. This explains the sharp rise in non-marriage among tertiary-educated women in recent years (DOSM, 2012; Tey, 2007).

Educational homogamy increased by more than 11 percentage points, with a corresponding decrease of educational hypergamy by about 12 percentage points. The declining trend in hypergamy is closely related to the reversal in the gender gap in education in favour of the female since the 1990s. With modernisation, the norm of women marrying up may be changing (Chen and Chen, 2014; Raymo and Iwasawa, 2005; Utomo, 2014). However, the rising singlehood among the tertiary-educated, especially among the Chinese indicates that the expectation for a woman to marry someone with at least the same educational level is still strong.

The literature reviewed in the introductory section of this paper provides ample evidence on the positive effects of age and educational homogamy, 
such as the reduced risk of marital instability. However, contrary to expectation, the narrowing of the spousal age and educational gaps has occurred concurrently with the rising divorce rate in Malaysia (see Jones, 2021 in this issue). One plausible explanation is that an "empowered" woman can choose to terminate a marriage that does not meet her expectation.

Education has been cited as an important factor in intermarriage. Furtado (2012) argues that human capital enables easier adaptation to a different culture, greater mixing, and assortative matching on education. Consistent with the finding of Hassan and Benjamin (1973), this analysis found that education was not a significant factor in inter-ethnic marriage. Rising levels of education has resulted in increased female labour force participation. This analysis found that more and more women were engaged in a paid job. In light of the escalating cost of living, women's economic independence and contribution to the household economy have become increasingly important for a marriage (Musick et al., 2020). Working women are struggling to cope with their multiple roles in the family and workplace. Some women, including the highly educated, have stopped working to look after their babies while others have avoided childbearing to pursue their careers. There is a need for the government and employers to provide working women with childcare support, and the males should also share the family responsibilities.

This analysis found that inter-ethnic marriage had remained at around $4.2 \%-4.6 \%$ over the period 1991-2010, after rising from about $1 \%$ in the 1980 s. Intermarriage is more common among the minority groups with a small population base, and in ethnically more diverse Sabah and Sarawak than in Peninsular Malaysia. The findings on the rise in inter-ethnic marriage lend support to the theory of homogeneity and structural theory. Nagaraj (2009) argued that dominant communities might have strong family organisations that create barriers to intermarriage. However, these barriers weaken in the culturally diverse environments where the young and better educated seek work or where a spouse of the same ethnicity is limited.

The estimates based on census data probably represent an undercount of inter-ethnic marriage because marriages between the sub-groups of the Other Bumiputera were not taken into account. Moreover, in population censuses, an individual's ethnic identity was self-classified. An individual may report his or her ethnic identity to follow that of the spouse. The rise of inter-ethnic marriage implies declining social distance, with significant 
consequences on the ethnic fabric of the country. An online survey conducted in 2020, covering 1,202 married persons across Sabah showed that 38.6\% of the marriages in the state were between different ethnic groups (Tey, forthcoming), much higher than the $11 \%$ reported for the country as a whole. The figure is indicative of the higher intermarriage rate in Sabah because of its ethnically diverse population, and the presence of a large number of non-citizens, which made up more than a quarter of the state population. The intermarriage rate among those aged below 30 was about 9 percentage points higher than those aged 50 and over. The intermarriage rate among the tertiary-educated women was twice as high as those with no schooling (48\% versus $21.8 \%$ ). Urban residents were more likely than rural residents to have a spouse from other ethnic groups.

Inter-ethnic marriage has far-reaching consequences on the ethnic composition of the population and the social fabric. The offspring of a mixed marriage have to pick either parent's ethnic group, usually that of the father (Chong, 2009). In Malaysia, in mixed marriages with Malays, the family is Muslim, and the children refer to themselves as Malay. Also, the children from mixed marriages between Bumiputera and non-Bumiputera mostly identify themselves as Bumiputera. Hence, inter-ethnic marriages will result in changing the ethnic composition. For instance, the total fertility rate of Sabah's Chinese has fallen to an extremely low level of 0.6 in 2019 (DOSM, 2020a), as $42 \%$ of the Chinese men and $18 \%$ of Chinese women were found to out-marry (Tey, forthcoming).

Non-citizens make up about $10 \%$ of the national population and as many as $30 \%$ of Sabah's population. Except for Sabah, marriage with foreigners remains at a low level among the main ethnic groups, despite the presence of a large number of non-citizens in the country. Most non-citizens are migrant workers on temporary work passes. The low rate of intermarriage between locals and migrants is partly due to the enforcement of strict immigration rules and laws, which put the foreign spouse and their children at a great disadvantage (Favero-Karunaratna, 2004).

With the escalating cost of living, more and more women are engaged in paid jobs to contribute to the household economy. This analysis found that the proportion of women who were working had increased by almost 10 percentage points over the period 1991-2010. All these changes are expected to impact gender relations and the power dynamics of Malaysian families. Many working women are having difficulty in coping with their roles as 
workers and homemakers. In the absence of adequate childcare support, some women choose to forgo their careers, while others forgo childbearing, resulting in ultra-low fertility among some segments of the population.

\section{Conclusion}

The changes in the spousal differentials in socio-demographic characteristics, the rise in inter-ethnic and international marriages, and female labour force participation are bound to alter the gender roles and relations, which will impact family functioning and demographic outcomes, and socio-economic development. The present study identifies the gap in knowledge and directions for future research in this area. With rising age at marriage and non-marriage contributing to low fertility and social changes, there is a need for more research to guide policy formulation and program implementation to strengthen the marriage institution.

Some limitations of the study need to be recognized. The analysis was confined to a relatively short period, as the micro-data for the earlier population censuses were not available for Sabah and Sarawak. Also, data for this analysis is rather outdated and does not reflect the post-2010 changes in marriage institutions, such as the sharp rise in inter-ethnic marriages from $4.2 \%$ in 2010 to $8 \%$ in 2017 and $11 \%$ in 2019 . There may be significant changes in cross-border marriages, women's roles in the household economy, and spousal differentials in socio-demographic characteristics during the last decade, which calls for an update of this analysis once data from the 2020 population census are made available.

The literature shows that age at marriage is an important determinant of the spousal differentials in age, education, and ethnicity. However, as past Malaysian censuses did not collect information on age at first marriage, an analysis of the effect of the marriage timing on spousal differentials in sociodemographic characteristics could not be performed. The lack of information also precludes an analysis of the association between spousal differentials in socio-demographic characteristics and marital stability, childbearing, women's role, and domestic violence. 


\section{Acknowledgement}

The authors would like to thank the Department of Statistics, Malaysia for permission to use the data for this analysis.

\section{Funding}

This work was supported by the National Population and Family Development Board, Malaysia (Grant No.: GA025-2021).

\section{References}

Amin, S., \& Jepsen, L. K. (2005). The impact of a wife's education on her husband's earnings in Malaysia. Journal of Economic Insight (formerly the Journal of Economics (MVEA)), 31(2), 1-18.

Arshat, H., Tan, B. A., Tey, N. P., \& Subbiah, M. (1988). Marriage and Family Formation in Peninsular Malaysia: Analytic Report on the 1984/85 Malaysian Population and Family Survey. Kuala Lumpur, Malaysia: National Population and Family Development Board.

Barich, R. R., \& Bielby, D. D. (1996). Rethinking marriage: Change and stability in expectations, 1967-1994. Journal of Family Issues, 17(2), 139-169. https://doi.org/10.1177/019251396017002001

Becker, G. S. (1974). A theory of marriage: Part II. Journal of Political Economy, 82(2, Part 2), S11-S26. https://doi.org/10.1086/260287

Benham, L. (1974). Benefits of women's education within marriage. Journal of Political Economy, 82(2, Part 2), S57-S71. https://doi. org/10.1086/260291

Berardo, F. M., Appel, J., \& Berardo, D. H. (1993). Age dissimilar marriages: Review and assessment. Journal of Aging Studies, 7(1), 93106. https://doi.org/10.1016/0890-4065(93)90026-G

Blossfeld, H.-P. (2009). Educational assortative marriage in comparative perspective. Annual Review of Sociology, 35, 513-530. https://doi. org/10.1146/annurev-soc-070308-115913

Brown, D. C., Hummer, R. A., \& Hayward, M. D. (2014). The importance of spousal education for the self-rated health of married adults in the United States. Population Research and Policy Review, 33(1), 127-151. https:// doi.org/10.1007/s11113-013-9305-6 
Carmichael, S. (2011). Marriage and power: Age at first marriage and spousal age gap in lesser developed countries. The History of the Family, 16(4), 416-436. https://doi.org/10.1016/j.hisfam.2011.08.002

Casterline, J. B., Williams, L., \& McDonald, P. (1986). The age difference between spouses: Variations among developing countries. Population Studies, 40(3), 353-374. https://doi.org/10.1080/0032472031000142296

Chen, Y.-H., \& Chen, H. (2014). Continuity and changes in the timing and formation of first marriage among postwar birth cohorts in Taiwan. Journal of Family Issues, 35(12), 1584-1604. https://doi. org $/ 10.1177 / 0192513 X 14538026$

Chong, B. S.-Y. (2009). A note on Malaysians of mixed parentage. Malaysian Journal of Economic Studies, 46(1), 93-95.

Clarkwest, A. (2007). Spousal dissimilarity, race, and marital dissolution. Journal of Marriage and Family, 69(3), 639-653. https://doi.org/10.1111/ j.1741-3737.2007.00397.x

DOSM. (2011). Population and Housing Census of Malaysia: Population Distribution and Basic Demographic Characteristics, 2010. DOSM, Putrajaya: Malaysia.

DOSM. (2012). Population and Housing Census of Malaysia 2010 Education and Social Characteristics of the Population. DOSM, Putrajaya: Malaysia.

DOSM. (2020a). Laporan Sosioekonomi Negeri Sabah 2019. DOSM, Putrajaya: Malaysia.

DOSM. (2020b). Marriage and Divorce Statistics, Malaysia, 2020. DOSM, Putrajaya: Malaysia.

Drefahl, S. (2010). How does the age gap between partners affect their survival? Demography, 47(2), 313-326. https://doi.org/10.1353/dem.0.0106

Esteve, A., Schwartz, C. R., van Bavel, J., Permanyer, I., Klesment, M., \& García-Román, J. (2016). The end of hypergamy: Global trends and implications. Population and Development Review, 42(4), 615-625. https://doi.org/10.1111/padr.12012

Favero-Karunaratna, R. (2004). Mixed marriages and nation building processes: Sri Lanka and Malaysia. Identity, Culture and Politics, 5(1 \& 2), 124-134.

Foster, D., Klinger-Vartabedian, L., \& Wispé, L. (1984). Male longevity and age differences between spouses. Journal of Gerontology, 39(1), 117120. https://doi.org/10.1093/geronj/39.1.117 
Furtado, D. (2012). Human capital and interethnic marriage decisions. Economic Inquiry, 50(1), 82-93. https://doi.org/10.1111/j.14657295.2010.00345.x

Giok, H. P., \& Sulaiman, N. (2013). "Choose one!": Challenges of interethnic marriages in Malaysia. Asian Social Science, 9(17), 269-278. https://doi.org/10.5539/ass.v9n17p269

Grow, A., Schnor, C., \& Van Bavel, J. (2017). The reversal of the gender gap in education and relative divorce risks: A matter of alternatives in partner choice? Population Studies, 71(sup1), 15-34. https://doi.org/10.1080/00 324728.2017 .1371477

Han, H. (2010). Trends in educational assortative marriage in China from 1970 to 2000. Demographic Research, 22(24), 733-770. https://doi. org/10.4054/DemRes.2010.22.24

Hassan, R., \& Benjamin, G. (1973). Ethnic outmarriage rates in Singapore: The influence of traditional socio-cultural organization. Journal of Marriage and Family, 35(4), 731-738. https://doi.org/10.2307/350886

Heard, G. (2011). Socioeconomic marriage differentials in Australia and New Zealand. Population and Development Review, 37(1), 125-160. https:// doi.org/10.1111/j.1728-4457.2011.00392.x

Hu, A., \& Qian, Z. (2015). Educational homogamy and earnings inequality of married couples: Urban China, 1988-2007. Research in Social Stratification and Mobility, 40, 1-15. https://doi.org/10.1016/j. rssm.2015.01.004

Hu, Y., \& Qian, Y. (2019). Educational and age assortative mating in China: The importance of marriage order. Demographic Research, 41(3), 53-82. https://doi.org/10.4054/DemRes.2019.41.3

Huang, C., Li, H., Liu, P. W., \& Zhang, J. (2009). Why does spousal education matter for earnings? Assortative mating and crossproductivity. Journal of Labor Economics, 27( 4), 633-652. https://doi. org/10.1086/644746

Jaffe, D. H., Eisenbach, Z., Neumark, Y. D., \& Manor, O. (2006). Effects of husbands' and wives' education on each other's mortality. Social Science \& Medicine, 62(8), 2014-2023. https://doi.org/10.1016/j. socscimed.2005.08.030

Jolly, N. A. (2019). Female earnings and the returns to spousal education over time. Journal of Family and Economic Issues, 40, 691-709. https:// doi.org/10.1007/s10834-019-09637-z 
Jones, G. W. (1980). Trends in marriage and divorce in Peninsular Malaysia. Population Studies, 34(2), 279-292. https://doi.org/10.1080/00324728.1 980.10410390

Jones, G. W. (1981). Malay marriage and divorce in Peninsular Malaysia: Three decades of change. Population and Development Review, 7(2), 255-278. https://doi.org/10.2307/1972623

Jones, G. W. (2020). Family and marriage in Malaysia. In N. P. Tey, S. L. Lai, \& N. A. Ismail (Eds.), Demographic Transition and Socio-economic Development in Malaysia (pp. 75-92). Kuala Lumpur, Malaysia: University of Malaya Press.

Kalmijn, M. (1991). Status homogamy in the United States. American Journal of Sociology, 97(2), 496-523. https://doi.org/10.1086/229786

Kalmijn, M. (1998). Intermarriage and homogamy: Causes, patterns, trends. Annual Review of Sociology, 24, 395-421. https://doi.org/10.1146/ annurev.soc.24.1.395

Kenny, L. W. (1983). The accumulation of human capital during marriage by males. Economic Inquiry, 21(2), 223-231. https://doi. org/10.1111/j.1465-7295.1983.tb00627.x

Klinger-Vartabedian, L., \& Wispe, L. (1989). Age differences in marriage and female longevity. Journal of Marriage and Family, 51(1), 195-202. https://doi.org/10.2307/352380

Kravdal, Ø. (2008). A broader perspective on education and mortality: Are we influenced by other people's education? Social Science \& Medicine, 66(3), 620-636. https://doi.org/10.1016/j.socscimed.2007.10.009

Kuo, E. C. Y., \& Hassan, R. (1976). Some social concomitants of interethnic marriage in Singapore. Journal of Marriage and Family, 38(3), 549-559. https://doi.org/10.2307/350423

Lefgren, L., \& McIntyre, F. (2006). The relationship between women's education and marriage outcomes. Journal of Labor Economics, 24(4), 787-830. https://doi.org/10.1086/506486

Luoh, M.-C. (2001). Differences in educational attainment across ethnic and gender groups in Taiwan. Taiwan Economic Review, 29(2), 117-152.

Malinen, K., Kinnunen, U., Tolvanen, A., Rönkä, A., Wierda-Boer, H., \& Gerris, J. (2010). Happy spouses, happy parents? Family relationships among Finnish and Dutch dual earners. Journal of Marriage and Family, 72(2), 293-306. https://doi.org/10.1111/j.1741-3737.2010.00700.x 
Manning, W. D., Brown, S. L., \& Payne, K. K. (2014). Two decades of stability and change in age at first union formation. Journal of Marriage and Family, 76(2), 247-260. https://doi.org/10.1111/jomf.12090

Mano, Y., \& Yamamura, E. (2013). Influence of a wife's working status on her husband's accumulation of human capital. Asian Economic Journal, 27(4). https://doi.org/10.1111/asej.12017

Mare, R. D. (1991). Five decades of educational assortative mating. American Sociological Review, 56(1), 15-32. https://doi.org/10.2307/2095670

Mensch, B. (1986). Age differences between spouses in first marriages. Social Biology, 33(3-4), 229-240. https://doi.org/10.1080/19485565.19 86.9988641

Monden, C. W. S., van Lenthe, F., De Graaf, N. D., \& Kraaykamp, G. (2003). Partner's and own education: Does who you live with matter for self-assessed health, smoking and excessive alcohol consumption? Social Science \& Medicine, 57(10), 1901-1912. https://doi.org/10.1016/ S0277-9536(03)00055-8

Musick, K., Bea, M. D., \& Gonalons-Pons, P. (2020). His and her earnings following parenthood in the United States, Germany, and the United Kingdom. American Sociological Review, 85(4), 639-674. https://doi. org/10.1177/0003122420934430

Nagaraj, S. (2009). Intermarriage in Malaysia. Malaysian Journal of Economic Studies, 46(1), 75-92.

Nye, F. I., \& Berardo, F. M. (1975). Theoretical perspectives on spouse selection. In J. R. Delora \& J. S. Dolara (Eds.), Intimate lifestyles (pp. 5-11). California, United States: Goodyear Publishing.

Pearlin, L. I. (1975). Status inequality and stress in marriage. American Sociological Review, 40(3), 344-357. https://doi.org/10.2307/2094462

Piotrowski, M., Tong, Y., Zhang, Y., \& Chao, L. (2016). The transition to first marriage in China, 1966-2008: An examination of gender differences in education and hukou status. European Journal of Population, 32, 129-154. https://doi.org/10.1007/s10680-015-9364-y

Qian, Y. (2017). Gender asymmetry in educational and income assortative marriage. Journal of Marriage and Family, 79(2), 318-336. https://doi. org/10.1111/jomf.12372

Qian, Y., \& Qian, Z. (2014). The gender divide in urban China: Singlehood and assortative mating by age and education. Demographic Research, 31(45), 1337-1364. https://doi.org/10.4054/DemRes.2014.31.45 
Qian, Y., \& Qian, Z. (2017). Assortative mating by education and hukou in Shanghai. Chinese Sociological Review, 49(3), 239-262. https://doi.org/ 10.1080/21620555.2017.1288066

Rapp, D., Zoch, B., Khan, M. M. H., Pollmann, T., \& Krämer, A. (2012). Association between gap in spousal education and domestic violence in India and Bangladesh. BMC Public Health, 12(467). https://doi. org/10.1186/1471-2458-12-467

Raymo, J. M., \& Iwasawa, M. (2005). Marriage market mismatches in Japan: An alternative view of the relationship between women's education and marriage. American Sociological Review, 70(5), 801-822. https://doi.org/10.1177/000312240507000504

Schofer, E., \& Meyer, J. W. (2005). The worldwide expansion of higher education in the twentieth century. American Sociological Review, 70(6), 898-920. https://doi.org/10.1177/000312240507000602

Schwartz, C. R., \& Mare, R. D. (2005). Trends in educational assortative marriage from 1940 to 2003. Demography, 42(4), 621-646. https://doi. org $/ 10.1353 /$ dem. 2005.0036

Shehan, C. L., Berardo, F. M., Vera, H., \& Carley, S. M. (1991). Women in age-discrepant marriages. Journal of Family Issues, 12(3), 291-305. https://doi.org/10.1177/019251391012003003

Smits, J., Ultee, W., \& Lammers, J. (1998). Educational homogamy in 65 countries: An explanation of differences in openness using country-level explanatory variables. American Sociological Review, 63(2), 264-285. https://doi.org/10.2307/2657327

Song, L. (2009). The effect of the cultural revolution on educational homogamy in urban China. Social Forces, 88(1), 257-270. https://doi. org/10.1353/sof.0.0246

Tan, P. C., \& Jones, G. W. (1990). Changing patterns of marriage and household formation in Peninsular Malaysia. Sojourn: Journal of Social Issues in Southeast Asia, 5(2), 163-193. https://doi.org/10.1355/sj5-2a

Tan, T. (2018). More mixed marriages registered in Singapore. Straits Times. https://www.straitstimes.com/singapore/more-mixed-marriagesregistered-last-year

Tey, N. P. (2007). Trends in delayed and non-marriage in Peninsular Malaysia. Asian Population Studies, 3(3), 243-261. https://doi. org/10.1080/17441730701746391 
Tey, N. P. (2011). Understanding marriage and divorce trends in Peninsular Malaysia. In G. W. Jones, T. H. Hull, \& M. Mohamad (Eds.), Changing Marriage Patterns in Southeast Asia: Economic and Socio-cultural Dimensions (pp. 137-155). London, England: Routledge.

Tey, N. P. (forthcoming). Marriage trends and patterns in Sabah. In N. P. Tey, S. L. Lai, \& K. L. Chan (Eds.), Population and Family in Sabah. Sabah, Malaysia: UMS Press.

Tey, N. P., Ng, S. T., \& Yew, S. Y. (2012). Proximate determinants of fertility in Peninsular Malaysia. Asia-Pacific Journal of Public Health, 24(3), 495-505. https://doi.org/10.1177/1010539511401374

Tiefenthaler, J. (1997). The productivity gains of marriage: Effects of spousal education on own productivity across market sectors in Brazil. Economic Development and Cultural Change, 45(3), 633-650. https:// doi.org/10.1086/452294

Utomo, A. J. (2014). Marrying up? Trends in age and education gaps among married couples in Indonesia. Journal of Family Issues, 35(12), 16831706. https://doi.org/10.1177/0192513X14538023

Van de Putte, B., Van Poppel, F., Vanassche, S., Sanchez, M., Jidkova, S., Eeckhaut, M., . . . Teachman, J. (2009). The rise of age homogamy in 19th century western Europe. Journal of Marriage and Family, 71(5), 1234-1253. https://doi.org/10.1111/j.1741-3737.2009.00666.x

Vera, H., Berardo, D. H., \& Berardo, F. M. (1985). Age heterogamy in marriage. Journal of Marriage and Family, 47(3), 553-566. https://doi. org $/ 10.2307 / 352258$

World Bank. (2021). World Development Indicators. https://datacatalog. worldbank.org/dataset/world-development-indicators

Yamamura, E., \& Mano, Y. (2012). An investigation into the positive effect of an educated wife on her husband's earnings: The case of Japan in the period between 2000 and 2003. International Advances in Economic Research, 18, 409-416. https://doi.org/10.1007/s11294-012-9368-x

Yang, C.-L., Li, T.-C., \& Chen, K.-J. (2006). Assortative mating in Taiwan: Changes and persistence. Journal of Population Studies, 33, 1-32. 